\title{
Биохимия
}

\section{B IOCHEMISTRY}

УДК 577.19+615.017

\section{СРАВНИТЕАЬНАЯ ОЦЕНКА ГЕПАТОПРОТЕКТОРНЫХ СВОЙСТВ РАСТИТЕАЬНЫХ АААПТОГЕНОВ НА ЭКСПЕРИМЕНТААЬНОЙ МОАЕЛИ ХРОНИЧЕСКОГО АЛКОГОАЬНОГО ПОРАЖЕНИЯ ПЕЧЕНИ in vivo}

\author{
О. И. ГУБИЧ ${ }^{1)}$, Я. Ю. ДАШКОВА ${ }^{1)}$ И. Н. КРИВЛЕНЯ ${ }^{1)}$ \\ ${ }^{1)}$ Белорусский государственный университет, пр. Независимости, 4, 220030, г. Минск, Беларусь
}

Изучена эффективность коррекции величин биохимических маркеров поражения печени и перекисного окисления липидов препаратами растительных адаптогенов (железницы крымской (Sideritis scardica), суданской розы (Hibiscus sabdariffa), рододендрона Адамса (Rhododendron adamsii Rehder)) у лабораторных крыс в экспериментальной модели хронической алкогольной интоксикации. Показано, что употребление всех исследованных препаратов в определенной мере способствует нормализации клинических показателей поражения печени (активность щелочной фосфатазы и аланинаминотрансферазы, содержание свободного и связанного билирубина в сыворотке крови) и перекисного окисления липидов подопытных животных (содержание восстановленных SH-групп и ТБК-активных продуктов, активность каталазы и супероксиддисмутазы в гомогенате печени). В использованной модели наиболее выраженные антиоксидантные и защитные эффекты, сопоставимые с действием классических препаратов гепатопротекторного ряда «Гепсил-Рн» и «Эссенциале форте», проявляли отвары железницы крымской и рододендрона Адамса, что может быть обусловлено высоким содержанием в их составе флавоноидов и ненасыщенных жирных кислот.

Ключевые слова: адаптоген; хроническая алкогольная интоксикация; сыворотка крови; гепатопротекция; перекисное окисление липидов; «Эссенциале форте».

Образец цитирования:

Губич ОИ, Дашкова ЯЮ, Кривленя ИН. Сравнительная оценка гепатопротекторных свойств растительных адаптогенов на экспериментальной модели хронического алкогольного поражения печени in vivo. Журнал Белорусского государственного университета. Биология. 2019;1:54-62. https://doi.org/10.33581/2521-1722-2019-1-54-62

\section{For citation:}

Hubich AI, Dashkova YaYu, Krivlenya IN. The comparative evaluation of plant adaptogenes' hepatoprotective properties on the experimental model of rat liver chronic alcohol damage in vivo. Journal of the Belarusian State University. Biology. 2019;1:54-62. Russian.

https://doi.org/10.33581/2521-1722-2019-1-54-62

\section{А в т о ры:}

Оксана Игоревна Губич - кандидат биологических наук, доцент; доцент кафедры биохимии биологического факультета.

Яна Юрьевна Дашкова - студентка биологического факультета. Научный руководитель - О. И. Губич.

Инна Николаевна Кривленя - студентка биологического факультета. Научный руководитель - О. И. Губич.

\author{
Authors: \\ Aksana I. Hubich, $\mathrm{PhD}$ (biology), docent; associate professor \\ at the department of biochemistry, faculty of biology. \\ hubich_oksana@tut.by \\ Yana $\overline{Y u}$. Dashkova, student at the faculty of biology. \\ yanadashkova_98@mail.ru \\ Ina $N$. Krivlenya, student at the faculty of biology. \\ inna_krivlenya@mail.ru
}




\title{
THE COMPARATIVE EVALUATION OF PLANT ADAPTOGENES' HEPATOPROTECTIVE PROPERTIES ON THE EXPERIMENTAL MODEL OF RAT LIVER CHRONIC ALCOHOL DAMAGE in vivo
}

\author{
A. I. HUBICH , Ya. Yu. DASHKOVA , I. N. KRIVLENYA ${ }^{\text {a }}$ \\ a Belarusian State University, 4 Niezaliežnasci Avenue, Minsk 220030, Belarus \\ Corresponding author: A. I. Hubich (hubich_oksana@tut.by)
}

\begin{abstract}
This work is devoted to the study of the effectiveness of biochemical liver damage markers and lipid peroxidation correction by plant adaptogens (Sideritis scardica, Hibiscus sabdariffa, Rhododendron adamsii Rehder) in laboratory rats with experimental chronic alcohol intoxication. It was shown that the using of all drugs studied contributes to the normalization of liver damage indicators (alkaline phosphatase and alanine aminotransferase activity, the content of free and bound bilirubin in the blood serum) and lipid peroxidation markers (the content of reduced SH-groups and TBA-active products, catalase and superoxide dismutase activity in the liver homogenate). It was demonstrated that the most pronounced antioxidant and hepatoprotective effects in this model, comparable to the action of classical hepatoprotectors «Hepsil-Rn» and «Essentiale Forte», had decoctions of Sideritis scardica and Rhododendron adamsii Rehder which may be due to the high content of flavonoids and unsaturated fatty acids in their composition.
\end{abstract}

Key words: adaptogen; chronic alcohol intoxication; blood serum; hepatoprotection; lipid peroxidation; «Essentiale Forte».

\section{Введение}

Злоупотребление спиртными напитками распространено повсеместно и представляет серьезную проблему медицинского и социального плана. Согласно экспертным оценкам, по причине злоупотребления алкоголем ежегодно в мире умирает около 1,8 млн человек, что составляет примерно 3,2 \% общего уровня смертности [1]. Токсическое действие этанола на организм человека сложно и многообразно. Известно, что этиловый спирт оказывает влияние на центральную нервную систему, функционирование печени, легких, форменных элементов крови, регенерацию тканей [2]. При значительном употреблении алкоголя включаются прямые механизмы цитотоксического влияния, развиваются электролитные нарушения, активируются аутоиммунные процессы, перекисное окисление липидов (ПОЛ), происходит накопление эстерифицированных жирных кислот, развивается алкогольная болезнь сердца [3]. Доказан нейровоспалительный механизм этанолиндуцированного повреждения мозга за счет нарушения функционирования транскрипционного фактора NF-кB [4]. На фоне алкогольного опьянения замедляются процессы реэпителизации и ангиогенеза при повреждении кожных покровов [2]. К иным значимым алкогольиндуцированным болезням и состояниям относят артериальную гипертензию, аритмию, порфирии, гиперлипопротеинемию, периферическую нейропатию, деменцию, туберкулез, эндокардит, псориаз, гастрит, гастроэзофагеальную рефлюксную болезнь [5].

По данным Всемирной организации здравоохранения, 70 \% пациентов, злоупотребляющих алкоголем, страдают алкогольной болезнью печени (АБП), проявляющейся 3 основными формами: жировой дистрофией (60-90 \% случаев), алкогольным гепатитом (10-30\%) и циррозом печени (8-20 \%) [6]. Наиболее опасным при развитии АБП является ежедневный прием алкоголя, тогда как периодический не лишает печень способности к регенерации.

На сегодня механизмы этанольного поражения печени хорошо изучены. Основные звенья патогенеза в данном случае связаны с воздействием эндотоксинов, развитием окислительного стресса и воспаления [6]. Установлено, что метаболизм этанола в печени осуществляется при помощи 3 ферментных систем: алкогольдегидрогеназы, цитохрома $\mathrm{P}_{450} 2 \mathrm{E} 1$ (CYP2E1) и каталазы [7]. Под действием алкогольдегидрогеназы и СYР2Е1 алкоголь метаболизируется в ацетальдегид, который является высокореактивным и потенциально токсичным соединением, а также проявляет канцерогенные свойства, повышая риск развития гепатоцеллюлярного рака [7-9]. Ацетальдегид оказывает повреждающее действие на гепатоциты, вызывая разрушение биологических мембран и некроз клеток печени. Он усиливает синтез триацилглицеринов и способствует их отложению в гепатоцитах, ингибирует синтез альбумина и нарушает обезвреживающую функцию печени по отношению к экзогенным токсинам, стимулирует процессы фиброгенеза, нарушает метаболизм пиридоксиновых кофакторов ферментов и витаминов группы E [10]. Метаболизм этанола сопровождается увеличением продукции активных форм кислорода, включая гидроксильные радикалы и супероксидный анион, что приводит к индукции ПОЛ, повреждению структуры белков и митохондриальной ДНК, что, в свою очередь, снижает энергетический баланс клетки [11]. 
В клинической практике для терапии АБП традиционно используются гепатопротекторы, антихолестатические и витаминные препараты [12]. Воспалительная природа алкогольного гепатита и иммунологические нарушения предопределяют перспективность применения кортикостероидов. Повышение уровня восстановленного глутатиона, как основного эндогенного антиоксиданта, может быть достигнуто назначением предшественников цистеина - ацетилцистеина или S-аденозилметионина [13]. Среди гепатопротекторов растительного происхождения, проявляющих антиоксидантный эффект, особое место занимают препараты силимарина из расторопши пятнистой [14]. Вместе с тем поиск лекарственных средств, обладающих гепатопротекторной активностью и препятствующих развитию патологических процессов на фоне снижения эндогенной антиоксидантной защиты, по-прежнему не теряет своей актуальности.

Современные подходы в фармакотерапии острой интоксикации этанолом разрабатывают исходя из необходимости усиливать детоксикацию этанола в печени с минимальными побочными эффектами [15]. Подобным действием могут обладать препараты природных адаптогенов. Эффект данных соединений на организм человека многовекторный: они проявляют иммуностимулирующую активность и улучшают пластический обмен, стимулируют центральную нервную и эндокринную системы, модулируют избирательную проницаемость биологических мембран, оказывают антиоксидантное действие и активируют ферменты энергетического обмена, что приводит к нормализации обмена веществ [16; 17]. Среди прочих адаптогенов пристальное внимание привлекает к себе железница крымская (Sideritis scardica), характеризующаяся чрезвычайно богатым химическим составом, включающим дитерпены, гидрокарбоны, жирные кислоты, простые и сложные эфиры, алифатические и ароматические спирты, стеролы, тритерпены и монотерпены, таннины, флавины, благодаря чему данное растение уже используется как противовоспалительное, седативное, противомикробное, противоязвенное, антиоксидантное, спазмолитическое, противосудорожное [18-20].

Компоненты отвара суданской розы (Hibiscus sabdariffa), более известной как каркаде (органические кислоты, флавоноиды, антоцианы, аскорбиновая кислота), укрепляют стенки кровеносных сосудов, снижают артериальное давление, регулируют уровень холестерина в крови, проявляют иммуномодулирующую активность, обладают противовоспалительным, тонизирующим и антибактериальным действием [21].

Рододендрон Адамса (Rhododendron adamsii Rehder) широко применяется в тибетской и монгольской народной медицине благодаря своим адаптогенным, тонизирующим, антибактериальным, иммуностимулирующим, противовоспалительным и антиоксидантным свойствам [22]. Изучение химического состава позволило установить в его надземной части наличие флавоноидов, дубильных веществ, гликозидов, кумаринов, эфирных масел, жирных кислот, кислот с циклопропановым фрагментом, пренилированных фенолов [23; 24].

Ранее проведенное на кафедре биохимии биологического факультета БГУ исследование возможной коррекции изменений углеводного и белкового обмена у крыс с аллоксановым диабетом, равно как и у животных, находившихся на экспериментальной «ресторанной диете» с преобладанием легкоусвояемых углеводов, путем ежедневного введения отваров аптечных препаратов указанных выше растений подтверждает их эффективность $[25 ; 26]$. В то же время, несмотря на многочисленные фармакологические эффекты отваров и экстрактов данных растений, их способность оказывать стабилизирующее влияние на печень в условиях хронического алкогольного воздействия прежде не изучалась.

Цель данной работы - изучение влияния отваров железницы крымской (Sideritis scardica), суданской розы (Hibiscus sabdariffa) и рододендрона Адамса (Rhododendron adamsii Rehder) на биохимические маркеры поражения печени и показатели ПОЛ лабораторных крыс в экспериментальной модели хронической алкогольной интоксикации.

\section{Материалы и методы исследования}

Работа выполнена на беспородных белых крысах-самцах массой 180-200 г, находящихся на стандартной диете вивария БГУ. Все эксперименты осуществляли в соответствии с этическими нормами обращения с животными, а также правилами проведения работ с использованием лабораторных животных в научных исследованиях на биологическом факультете БГУ, составленными на основании рекомендаций и требований Всемирного общества защиты животных и Европейской конвенции по защите экспериментальных животных (Страсбург, 1986).

Для создания экспериментальной модели хронической алкогольной интоксикации 96 \% этанол разводили водой до 15 \% и предоставляли для питья (как альтернативу воде) в течение 6 недель лабораторным крысам, имеющим предрасположенность к алкоголизму, т. е. добровольно употреблявшим этиловый спирт в объеме 10-12 мл/сут. Указанная модель была разработана Институтом фармакологии имени А. В. Вальдмана (Санкт-Петербург) и использована нами без модификаций.

Применялись следующие аптечные препараты: трава железницы крымской (ООО «Русские корни», Россия), цветы суданской розы (ООО «НЕП», Россия), трава рододендрона Адамса (ООО «Иван-чай», 
Республика Бурятия, Россия). Во всех экспериментальных сериях отвар адаптогена готовили в соответствии с прилагающейся инструкцией и предоставляли группам экспериментальных животных вместо питьевой воды в течение 7 сут. Среднее потребление отвара составляло (15 \pm 5$)$ мл на крысу в сутки.

В качестве препарата сравнения использовали известный аптечный препарат гепатопротекторной группы «Эссенциале форте» (Nattermann \& Cie. GmbH, Германия), активным ингредиентом которого являются фосфолипиды соевых бобов, содержащие 76 \% холина. Данное средство рекомендуется пациентам с алкогольным гепатитом, токсическими поражениями печени, жировой дистрофией печени различной этиологии, циррозом печени, а также нарушениями функции печени при соматических заболеваниях [14]. «Эссенциале форте» в виде суспензии вводили интактным животным и крысам с алкогольным поражением печени в дозе 30 мг/кг в течение 7 сут перорально с помощью пипетки.

Как эталонный растительный препарат гепатопротекторного действия применяли «Гепсил-Рн» (ООО «Рубикон», Беларусь), активным фармацевтическим компонентом которого является сухой экстракт из плодов расторопши пятнистой, эквивалентный 35 мг силимарина [14]. «Гепсил-Рн» используется при алкогольном, вирусном, лекарственном, токсическом поражении печени, а также циррозах различной этиологии. Водную суспензию данного препарата вводили интактным животным и крысам с алкогольным поражением печени в дозе 9 мг/кг в течение 7 сут перорально с помощью пипетки.

По истечении указанного времени лабораторных животных выводили из эксперимента путем декапитации и проводили измерение активности аланинаминотрансферазы (АлАТ), щелочной фосфатазы (ЩФ), содержания билирубина и его фракций в сыворотке крови, а также активности каталазы и супероксиддисмутазы, содержания ТБК-активных продуктов и восстановленных SH-групп в гомогенате печени. Активность АлАТ и ЩФ определяли спектрофотометрическим методом с помощью коммерческих наборов реагентов, содержание билирубина - по методу Йендрашика [27], активность каталазы - как описано в [28], активность супероксиддисмутазы (СОД) - по методу Костюка [29], содержание восстановленных SH-групп - по методу Эллмана [30], содержание ТБК-активных продуктов - спектрофотометрическим методом [31].

Экспериментальные данные обрабатывали статистически с вычислением среднего арифметического $(X)$, стандартной ошибки среднего арифметического $\left( \pm S_{x}\right)$ и достоверности при уровне значимости $p \leq 0,05$. Для статистических расчетов использовали лицензионный пакет программ Stadia 6.0.

\section{Результаты и их обсуждение}

Как известно, этанол - это вещество, сочетающее в себе свойства естественного метаболита организма человека, токсичного ксенобиотика и алиментарного фактора, который способен существенно изменять эффективность лекарственной терапии [10]. Биотрансформация этанола в печени, как отмечалось выше, сопровождается образованием ацетальдегида, способного опосредованно активировать ПОЛ, что связано с его свойством снижать в гепатоцитах содержание восстановленного глутатиона, который абсолютно необходим для функционирования глутатионпероксидазы, участвующей в катаболизме $\mathrm{H}_{2} \mathrm{O}_{2}$ [32]. Накопление активных форм кислорода, в свою очередь, приводит к нарушению структуры липидного бислоя мембран клеток печени, что предопределяет возможность развития острого алкогольного гепатита и цирроза печени у алкоголиков [32]. Данный факт послужил основанием для изучения, наряду с классическими сывороточными маркерами поражения печени, интенсивности ПОЛ и активности ферментов антиоксидантной защиты (каталаза, СОД) в печени крыс в условиях хронической алкогольной интоксикации, вызванной ежедневным свободным употреблением 15 \% этанола. Результаты представлены в табл. 1 и 2.

Влияние отваров природных адаптогенов и препаратов гепатопротекторного ряда на показатели поражения печени в сыворотке крови интактных крыс и животных с экспериментальной алкогольной интоксикацией

Таблица 1

Table 1

The effect of natural adaptogens decoctions and hepatoprotective drugs on the liver damage markers in the blood serum of intact rats and animals with experimental alcohol intoxication

\begin{tabular}{|l|c|c|c|c|}
\hline \multicolumn{1}{|c|}{ Серия } & $\begin{array}{c}\text { Активность ЩФ, } \\
\text { мкмоль/л }\end{array}$ & $\begin{array}{c}\text { Активность АлАТ, } \\
\text { моль НАДН/мин }\end{array}$ & $\begin{array}{c}\text { Содержание } \\
\text { свободного } \\
\text { билирубина, } \\
\text { мкмоль/л }\end{array}$ & $\begin{array}{c}\text { Содержание } \\
\text { связанного } \\
\text { билирубина, } \\
\text { мкмоль/л }\end{array}$ \\
\hline Интактные крысы & $\begin{array}{c}205,5 \pm 17,5 \\
(100 \%)\end{array}$ & $\begin{array}{c}77,5 \pm 8,6 \\
(100 \%)\end{array}$ & $\begin{array}{c}8,4 \pm 1,2 \\
(100 \%)\end{array}$ & $\begin{array}{c}6,4 \pm 0,6 \\
(100 \%)\end{array}$ \\
\hline Алкогольное & $\begin{array}{c}420,0 \pm 19,9 \\
\text { поражение печени }\end{array}$ & $\begin{array}{c}144,5 \pm 2,1 \\
(186,5 \%)^{*}\end{array}$ & $\begin{array}{c}17,8 \pm 4,3 \\
(211,9 \%)^{*}\end{array}$ & $18,4 \pm 1,9$ \\
$(287,5 \%)^{*}$
\end{tabular}


Окончание табл.

Ending table

\begin{tabular}{|c|c|c|c|c|}
\hline Серия & $\begin{array}{c}\text { Активность ЩФ, } \\
\text { мкмоль/л }\end{array}$ & $\begin{array}{l}\text { Активность АлАТ, } \\
\text { моль НАДН/мин }\end{array}$ & $\begin{array}{c}\text { Содержание } \\
\text { свободного } \\
\text { билирубина, } \\
\text { мкмоль/л }\end{array}$ & $\begin{array}{c}\text { Содержание } \\
\text { связанного } \\
\text { билирубина, } \\
\text { мкмоль/л }\end{array}$ \\
\hline «Гепсил-Рн» (7 сут) & $\begin{array}{c}235,7 \pm 21,5 \\
(114,7 \%)\end{array}$ & $\begin{array}{l}90,3 \pm 2,7 \\
(116,9 \%)\end{array}$ & $\begin{array}{l}7,9 \pm 1,0 \\
(94,1 \%)\end{array}$ & $\begin{array}{c}6,7 \pm 0,8 \\
(104,7 \%)\end{array}$ \\
\hline «Эссенциале форте» (7 сут) & $\begin{array}{c}224,2 \pm 9,7 \\
(109,1 \%)\end{array}$ & $\begin{array}{l}88,2 \pm 3,4 \\
(113,8 \%)\end{array}$ & $\begin{array}{l}8,4 \pm 1,2 \\
(100 \%)\end{array}$ & $\begin{array}{l}7,1 \pm 0,7 \\
(110,1 \%)\end{array}$ \\
\hline $\begin{array}{l}\text { Отвар железницы } \\
\text { крымской (7 сут) }\end{array}$ & $\begin{array}{c}210,4 \pm 8,9 \\
(102,4 \%)\end{array}$ & $\begin{array}{l}74,5 \pm 7,4 \\
(96,1 \%)\end{array}$ & $\begin{array}{l}8,3 \pm 1,1 \\
(98,9 \%)\end{array}$ & $\begin{array}{l}5,9 \pm 0,7 \\
(92,2 \%)\end{array}$ \\
\hline $\begin{array}{l}\text { Отвар рододендрона } \\
\text { Адамса (7 сут) }\end{array}$ & $\begin{array}{l}224,0 \pm 23,1 \\
(109,0 \%)\end{array}$ & $\begin{array}{c}69,3 \pm 7,3 \\
(89,4 \%)\end{array}$ & $\begin{array}{l}9,7 \pm 2,5 \\
(115,5 \%)\end{array}$ & $\begin{array}{c}6,5 \pm 0,9 \\
(101,6 \%)\end{array}$ \\
\hline Отвар суданской розы (7 сут) & $\begin{array}{c}207,6 \pm 11,3 \\
(101,0 \%)\end{array}$ & $\begin{array}{c}68,3 \pm 7,3 \\
(89,4 \%)\end{array}$ & $\begin{array}{l}7,6 \pm 1,5 \\
(90,2 \%)\end{array}$ & $\begin{array}{l}7,4 \pm 1,3 \\
(116,1 \%)\end{array}$ \\
\hline $\begin{array}{l}\text { «Гепсил-Рн» на фоне } \\
\text { алкогольного поражения } \\
\text { печени }\end{array}$ & $\begin{array}{l}332,1 \pm 12,6 \\
(161,6 \%)^{* a}\end{array}$ & $\begin{array}{c}97,1 \pm 3,9 \\
(125,3 \%)^{* a}\end{array}$ & $\begin{array}{c}15,8 \pm 1,2 \\
(188,1 \%)^{\mathrm{a}}\end{array}$ & $\begin{array}{c}6,8 \pm 1,1 \\
(106,3 \%)^{* a}\end{array}$ \\
\hline $\begin{array}{l}\text { «Эссенциале форте» } \\
\text { на фоне алкогольного } \\
\text { поражения печени }\end{array}$ & $\begin{array}{l}285,4 \pm 11,1 \\
(138,9 \%)^{* a}\end{array}$ & $\begin{array}{l}112,2 \pm 1,8 \\
(144,8 \%)^{*^{a}}\end{array}$ & $\begin{array}{c}8,7 \pm 0,7 \\
(103,3 \%)^{*^{a}}\end{array}$ & $\begin{array}{c}7,7 \pm 0,9 \\
(120,1 \%)^{* a}\end{array}$ \\
\hline $\begin{array}{l}\text { Отвар железницы крымской } \\
\text { на фоне алкогольного } \\
\text { поражения печени }\end{array}$ & $\begin{array}{l}275,3 \pm 14,1 \\
(133,9 \%)^{* a}\end{array}$ & $\begin{array}{l}72,0 \pm 4,8 \\
(92,9 \%)^{* a}\end{array}$ & $\begin{array}{c}8,7 \pm 1,2 \\
(103,6 \%)^{* a}\end{array}$ & $\begin{array}{c}7,6 \pm 1,0 \\
(118,8 \%)^{* a}\end{array}$ \\
\hline $\begin{array}{l}\text { Отвар рододендрона Адамса } \\
\text { на фоне алкогольного } \\
\text { поражения печени }\end{array}$ & $\begin{array}{c}402,1 \pm 11,2 \\
(195,7 \%)\end{array}$ & $\begin{array}{c}84,7 \pm 2,7 \\
(109,3 \%)^{* a}\end{array}$ & $\begin{array}{l}11,6 \pm 2,7 \\
(138,1)^{*^{a}}\end{array}$ & $\begin{array}{c}5,8 \pm 1,2 \\
(90,6 \%)^{* a}\end{array}$ \\
\hline $\begin{array}{l}\text { Отвар суданской розы } \\
\text { на фоне алкогольного } \\
\text { поражения печени }\end{array}$ & $\begin{array}{l}368,1 \pm 10,3 \\
(179,3 \%)^{*^{a}}\end{array}$ & $\begin{array}{c}141,7 \pm 7,3 \\
(182,9 \%)\end{array}$ & $\begin{array}{c}15,7 \pm 3,7 \\
(187,9 \%)^{* a}\end{array}$ & $\begin{array}{c}12,8 \pm 3,4 \\
(199,3 \%)^{* a}\end{array}$ \\
\hline
\end{tabular}

Пр и м е ч ан и е. Данные в таблице представлены в виде $X \pm S_{x} .{ }^{*},{ }^{* a}$ - результаты достоверны при $p \leq 0,05(n=5$ для каждой серии). Достоверность эффектов этанола, аптечных гепатопротекторов и растительных отваров оценивалась по отношению к показателям интактной серии (*), а эффектов коммерческих гепатопротекторов и растительных отваров, вводимых крысам с экспериментальным поражением печени, - по отношению к показателям животных с данной патологией, не получавших изучаемый препарат $\left({ }^{* a}\right)$.

Таблица 2

\begin{abstract}
Влияние отваров природных адаптогенов и препаратов гепатопротекторного ряда на показатели ПОЛ и активность ферментов антиоксидантной защиты печени интактных крыс и животных с экспериментальной алкогольной интоксикацией
\end{abstract}

Table 2

The effect of the natural adaptogens decoctions and hepatoprotective drugs on the indicators of lipid peroxidation and the antioxidant enzymes activity in liver of intact rats and animals with experimental alcohol intoxication

\begin{tabular}{|c|c|c|c|c|}
\hline Серия & $\begin{array}{c}\text { Содержание } \\
\text { SН-групп, } \\
\text { ммоль/л }\end{array}$ & $\begin{array}{c}\text { Содержание } \\
\text { ТБК-активных } \\
\text { продуктов, мкмоль/л }\end{array}$ & $\begin{array}{c}\text { Активность каталазы, } \\
\text { ммоль } \mathrm{H}_{2} \mathrm{O}_{2} / \\
\text { мг белка } \cdot \text { мин }\end{array}$ & Активность СОД, у. е. \\
\hline Интактные крысы & $\begin{array}{c}147,7 \pm 13,1 \\
(100 \%)\end{array}$ & $\begin{array}{c}0,44 \pm 0,1 \\
(100 \%)\end{array}$ & $\begin{array}{c}10,3 \pm 1,0 \\
(100 \%)\end{array}$ & $\begin{array}{c}221,1 \pm 8,7 \\
(100 \%)\end{array}$ \\
\hline $\begin{array}{l}\text { Алкогольное } \\
\text { поражение печени }\end{array}$ & $\begin{array}{l}88,8 \pm 7,1 \\
(60,1 \%)^{*}\end{array}$ & $\begin{array}{c}0,69 \pm 0,1 \\
(156,8 \%)^{*}\end{array}$ & $\begin{array}{c}14,1 \pm 1,7 \\
(140,2 \%)^{*}\end{array}$ & $\begin{array}{c}291,0 \pm 14,2 \\
(131,7 \%)^{*}\end{array}$ \\
\hline «Гепсил-Рн» (7 сут) & $\begin{array}{c}136,6 \pm 7,3 \\
(92,5 \%)\end{array}$ & $\begin{array}{l}0,51 \pm 0,1 \\
(115,9 \%)\end{array}$ & $\begin{array}{l}12,0 \pm 0,7 \\
(116,5 \%)\end{array}$ & $\begin{array}{c}219,7 \pm 14,9 \\
(99,4 \%)\end{array}$ \\
\hline
\end{tabular}




\begin{tabular}{|c|c|c|c|c|}
\hline Серия & $\begin{array}{l}\text { Содержание } \\
\text { SН-групп, } \\
\text { ммоль/л }\end{array}$ & $\begin{array}{c}\text { Содержание } \\
\text { ТБК-активных } \\
\text { продуктов, мкмоль/л }\end{array}$ & $\begin{array}{c}\text { Активность каталазы, } \\
\text { ммоль } \mathrm{H}_{2} \mathrm{O}_{2} / \\
\text { мг белка } \cdot \text { мин }\end{array}$ & Активность СОД, у. е. \\
\hline «Эссенциале форте» (7 сут) & $\begin{array}{l}141,8 \pm 16,7 \\
(96,1 \%)\end{array}$ & $\begin{array}{l}0,45 \pm 0,1 \\
(102,0 \%)\end{array}$ & $\begin{array}{l}11,6 \pm 1,1 \\
(113,1 \%)\end{array}$ & $\begin{array}{c}136,6 \pm 19,8 \\
(107,1 \%)\end{array}$ \\
\hline $\begin{array}{l}\text { Отвар железницы } \\
\text { крымской (7 сут) }\end{array}$ & $\begin{array}{l}143,3 \pm 11,7 \\
(97,0 \%)\end{array}$ & $\begin{array}{l}0,52 \pm 0,1 \\
(117,1 \%)\end{array}$ & $\begin{array}{l}15,4 \pm 1,0 \\
(149,3 \%)^{*}\end{array}$ & $\begin{array}{c}284,9 \pm 14,7 \\
(128,9 \%)^{*}\end{array}$ \\
\hline $\begin{array}{l}\text { Отвар рододендрона } \\
\text { Адамса (7 сут) }\end{array}$ & $\begin{array}{c}152,9 \pm 7,6 \\
(103,5 \%)\end{array}$ & $\begin{array}{c}0,43 \pm 0,1 \\
(97,7 \%)\end{array}$ & $\begin{array}{l}8,8 \pm 0,8 \\
(85,4 \%) \\
\end{array}$ & $\begin{array}{c}220,0 \pm 9,1 \\
(99,5 \%) \\
\end{array}$ \\
\hline $\begin{array}{l}\text { Отвар суданской } \\
\text { розы (7 сут) }\end{array}$ & $\begin{array}{c}143,3 \pm 4,6 \\
(97,1 \%)\end{array}$ & $\begin{array}{l}0,41 \pm 0,1 \\
(93,0 \%)\end{array}$ & $\begin{array}{l}9,8 \pm 1,7 \\
(95,2 \%)\end{array}$ & $\begin{array}{c}236,6 \pm 11,3 \\
(107,1 \%)\end{array}$ \\
\hline $\begin{array}{l}\text { «Гепсил-Рн» на фоне } \\
\text { алкогольного поражения } \\
\text { печени }\end{array}$ & $\begin{array}{l}116,5 \pm 5,6 \\
(78,9 \%)^{*^{a}}\end{array}$ & $\begin{array}{c}0,52 \pm 0,1 \\
(118,2 \%)^{* \mathrm{a}}\end{array}$ & $\begin{array}{l}19,2 \pm 0,8 \\
(136,2 \%)\end{array}$ & $\begin{array}{l}239,7 \pm 11,2 \\
(108,4 \%)^{* a}\end{array}$ \\
\hline $\begin{array}{l}\text { «Эссенциале форте» } \\
\text { на фоне алкогольного } \\
\text { поражения печени }\end{array}$ & $\begin{array}{c}128,5 \pm 19,6 \\
(87,9 \%)^{* a}\end{array}$ & $\begin{array}{c}0,60 \pm 0,1 \\
(136,0 \%)^{* a}\end{array}$ & $\begin{array}{l}12,3 \pm 0,7 \\
(119,0 \%)\end{array}$ & $\begin{array}{l}265,5 \pm 13,6 \\
(120,1 \%)^{* a}\end{array}$ \\
\hline $\begin{array}{l}\text { Отвар железницы крымской } \\
\text { на фоне алкогольного } \\
\text { поражения печени }\end{array}$ & $\begin{array}{c}116,7 \pm 12,1 \\
(79,1 \%)^{* a}\end{array}$ & $\begin{array}{c}0,47 \pm 0,1 \\
(107,5 \%)^{*^{\mathrm{a}}}\end{array}$ & $\begin{array}{c}11,9 \pm 1,2 \\
(116,1 \%)^{*^{\mathrm{a}}}\end{array}$ & $\begin{array}{l}240,9 \pm 13,2 \\
(109,2 \%)^{* a}\end{array}$ \\
\hline $\begin{array}{l}\text { Отвар рододендрона Адамса } \\
\text { на фоне алкогольного } \\
\text { поражения печени }\end{array}$ & $\begin{array}{c}102,1 \pm 4,2 \\
(69,1 \%)\end{array}$ & $\begin{array}{c}0,53 \pm 0,1 \\
(128,5 \%)^{* a}\end{array}$ & $\begin{array}{l}11,2 \pm 1,2 \\
(108,7)^{* \mathrm{a}}\end{array}$ & $\begin{array}{c}260,0 \pm 11,7 \\
(117,6 \%)\end{array}$ \\
\hline $\begin{array}{l}\text { Отвар суданской розы } \\
\text { на фоне алкогольного } \\
\text { поражения печени }\end{array}$ & $\begin{array}{l}167,8 \pm 9,3 \\
(88,3 \%)^{* a}\end{array}$ & $\begin{array}{l}0,66 \pm 7,3 \\
(150,3 \%)\end{array}$ & $\begin{array}{l}14,2 \pm 2,0 \\
(138,1 \%)\end{array}$ & $\begin{array}{l}329,4 \pm 17,1 \\
(149,1 \%)^{* a}\end{array}$ \\
\hline
\end{tabular}

П р и м е ч а н и е. Данные в таблице представлены в виде $X \pm S_{x} .{ }^{*},{ }^{* a}-$ результаты достоверны при $p \leq 0,05(n=5$ для каждой серии). Достоверность эффектов этанола, аптечных гепатопротекторов и растительных отваров оценивалась по отношению к показателям интактной серии (*), а эффектов коммерческих гепатопротекторов и растительных отваров, вводимых крысам с экспериментальным поражением печени, - по отношению к показателям животных с данной патологией, не получавших изучаемый препарат $\left({ }^{* a}\right)$.

Как следует из табл. 2, хроническое спаивание крыс этанолом приводило к выраженным изменениям всех анализируемых показателей: содержание ТБК-активных продуктов в печени возросло на $56,8 \%$, активность каталазы - на 40,2 \%, СОД - на 31,7 \%, фиксировалось снижение содержания восстановленных SH-групп на 40 \%, что хорошо согласуется как с первоначальной гипотезой, так и с данными литературы [33]. Нарушение антиоксидантного статуса гепатоцитов сопровождалось нарушением их функции, что обусловило увеличение активности маркерных ферментов печени в сыворотке крови подопытных крыс: АлАТ - на 86,5\%, ЩФ - на 104,4 \%, а также содержания свободного билирубина - на $111,9 \%$, связанного - на $187,5 \%$ (см. табл. 1 ).

На следующем этапе исследований крысам с хроническим алкогольным поражением печени вводили широко используемый в медицинской практике гепатопротектор «Эссенциале форте», применяемый для лечения алкогольной дистрофии печени, а также при других заболеваниях или нарушениях работы данного органа, включая патологии, вызванные лекарственными препаратами, оказывающими негативное влияние на печень [14]. Терапевтическое действие «Эссенциале форте» определяется наличием в его составе эссенциальных фосфолипидов, которые способствуют регулированию метаболизма липопротеинов в печени, транспортируя холестерин и нейтральные жиры к местам их окисления. Это становится возможным главным образом благодаря увеличению способности липопротеинов высокой плотности связываться с холестерином. Известно, что данный препарат оказывает нормализующее действие на сохранение и восстановление клеточной структуры печени, сохранение фосфолипидозависимых ферментных систем, торможение формирования соединительной ткани в печени, метаболизм липидов и белков, восстановление клеток печени, нормализацию дезинтоксикационной функции печени, стабилизацию синтеза желчи и снижение литогенного индекса при экскреции фосфолипидов [34]. 
Установлено, что после ежедневного применения в течение 7 сут препарата «Эссенциале форте» (30 мг/кг) в экспериментальной модели хронического алкогольного воздействия активность АлАТ снизилась на $41,7 \%$, ЩФ - на 65,5 \%, содержание свободного и связанного билирубина - на 108,6 и 167,4 \% соответственно. Описанные изменения сопровождались и некоторой стабилизацией величин изучаемых показателей ПОЛ и активностей ферментов антиоксидантной защиты: содержание ТБК-активных продуктов в гомогенате печени крыс снизилось на 20,8 \%, активность каталазы - на $21 \%$, наблюдалось повышение содержания восстановленных SH-групп на 27 \% по сравнению с показателями животных с хроническим поражением печени этанолом, не получавших препарат (см. табл. 1 и 2).

Аналогичные результаты были получены и при использовании коммерческого гепатопротектора растительного происхождения «Гепсил-Рн». Находящиеся в его составе биофлавоноиды обеспечили проявление выраженного антиоксидантного действия и способствовали частичному восстановлению функций гепатоцитов крыс, подвергшихся хроническому алкогольному воздействию (см. табл. 1 и 2). Таким образом, оба коммерческих препарата, использованных в качестве препаратов сравнения, несмотря на различный состав и механизм действия, проявили на использованной экспериментальной модели гепатопротекторные свойства.

На дальнейшем этапе исследований животным с хроническим поражением печени и интактным крысам в течение 7 сут предоставлялись для питья отвары анализируемых адаптогенов как альтернатива воде. Ежедневное потребление анализируемых отваров интактными крысами не сопровождалось изменением активности ферментов антиоксидантной защиты, маркеров ПОЛ и биохимических показателей поражения печени, что хорошо согласуется с основным постулатом теории адаптогенов Н. В. Лазарева, согласно которому терапевтическое действие данных соединений реализуется в неблагоприятных условиях, в благоприятных же действие адаптогенов не проявляется или реализуется минимально [35].

Анализ исследуемых показателей у крыс с алкогольным поражением печени, ежедневно употреблявших отвары адаптогенов, свидетельствует о их защитном действии, выраженном в разной степени. Максимальный эффект наблюдался при использовании отвара железницы крымской (см. табл. 1 и 2). Так, содержание ТБК-активных продуктов в печени крыс, получавших отвар, снизилось на 49,3 \%, активность СОД - на 22,7 \%, активность каталазы - на 24,1 \% по сравнению с животными, не получавшими отвар. Содержание восстановленных SH-групп возросло на 19,1 \%. Таким образом, способность железницы крымской подавлять интенсивность ПОЛ, описанная в литературе, была продемонстрирована и на модели хронического поражения печени алкоголем. По мнению большинства авторов, флавоноиды, их дигликозиды и незаменимые жирные кислоты определяют данную активность, проявляемую препаратами этого растения in vivo и in vitro [18; 19]. С антиоксидантной активностью коррелировали и гепатопротекторные свойства указанного отвара. Ежедневный его прием подопытными крысами сопровождался снижением активности ЩФ на 70,5 \%, АлАТ - на 93,6 \%, свободного и связанного билирубина - до значений, статистически неотличимых от уровня интактных животных.

Достоверное антиоксидантное и гепатопротекторное действие наблюдалось и при использовании препарата рододендрона Адамса, в составе которого, как отмечалось выше, также присутствуют биофлавоноиды, пренилированные фенолы и ненасыщенные жирные кислоты. По всей видимости, именно их присутствие позволило снизить величину ПОЛ и активность ферментов антиоксидантной защиты в печени крыс с хронической алкогольной интоксикацией (содержание ТБК-активных продуктов оказалось на 28,3 \% ниже соответствующего контроля, активность каталазы - на 31,5 \%; наблюдалась тенденция к снижению активности СОД), а также значения клинических маркеров повреждения гепатоцитов (активность АлАТ снизилась на 167 \%, свободного и связанного билирубина - на 73,8 и 196,9 \% соответственно).

Антиоксидантные свойства отвара суданской розы в использованной модели были выражены в наименьшей степени (см. табл. 2). Тем не менее его использование позволило снизить гепатотропное действие этанола, что нашло отражение в уменьшении активности ЩФ и обеих фракций билирубина в сыворотке крови подопытных животных (см. табл. 1).

\section{Заключение}

В соответствии с полученными результатами наиболее выраженным антиоксидантным и гепатопротекторным эффектом на крыс с экспериментальным алкогольным поражением печени, превосходящим по ряду показателей действие классических гепатопротекторов «Гепсил-Рн» и «Эссенциале форте», обладал отвар железницы крымской, что может быть обусловлено наличием в его составе флавоноидов и ненасыщенных жирных кислот, проявляющих антиоксидантные свойства, а также отвар рододендрона Адамса, антиоксидантный эффект которого был описан прежде на иных экспериментальных моделях. Полученные данные могут оказаться полезными для подбора оптимальных средств фитотерапии в целях профилактики заболеваний печени у пациентов, страдающих алкоголизмом. 


\section{Библиографические ссылки}

1. Афанасьев АВ, Афанасьев ВВ, Рубитель ЛТ. Острая интоксикаиия этиловым алкоголем. Санкт-Петербург: Интермедика; 2002.

2. Ильницкий АН, Жернакова НИ, Постникова ЛИ, Борисов ОА, Позднякова НМ. Молекулярные механизмы нейроиммуноэндокринных эффектов алкоголя и соматическая патология. Научные ведомости Белгородского государственного университета. Серия: Медицина. Фармация. 2011;13(4(99)):5-12.

3. Разводовский ЮЕ. Алкогольная кардиомиопатия: современное состояние проблемы. Здравоохранение. 2007;4:42-45.

4. Crews F, Nixon K, Kim D, Joseph J, Shukitt-Hale B, Qin L, et al. BHT blocks NF-kappaB activation and ethanol-induced brain damage. Alcoholism Clinical and Experimental Research. 2006;30(11):1938-1949. DOI: 10.1111/j.1530-0277.2006.00239.x.

5. Щеголев АИ, Туманова УН. Роль алкоголя в развитии рака печени. Международный журнал прикладных и фундаментальных исследований. 2017;11(2):223-227.

6. Walsh K, Alexander G. Alcoholic liver disease. Postgraduate Medical Journal. 2000;76(895):280-286. DOI: 10.1136/pmj.76. 895.280.

7. Seitz HK, Stickel F. Molecular mechanisms of alcohol-mediated carcinogenesis. Nature Reviews Cancer. 2007;7(8):599-612. DOI: $10.1038 / \mathrm{nrc} 2191$.

8. Кляритская ИЛ, Иськова ИА. Роль алкоголя в возникновении рака желудочно-кишечного тракта. Крымский терапевтический журнал. 2017;2(2):18-23.

9. Туманова УН, Щеголев АИ. Ангиогенез при гепатоцеллюлярном раке. Успехи современной биологии. 2015;135(2):164-176.

10. Еремина ЕЮ. Алкогольная болезнь печени. Архив внутренней медициныл. 2012;6(8):26-30. DOI: 10.20514/2226-67042012-0-6-50-54.

11. O'Shea RS, Dasarathy S, McCullough AJ. Alcoholic liver disease. Hepatology. 2010;51(1):307-328. DOI: 10.1002/hep.23258.

12. Шоломицкая ИА, Капралов НВ. Алкогольная болезнь печени. Минск: БГМУ; 2015.

13. Разводовский ЮЕ. Алкогольные поражения печени. Медицинские новости. 2003;7:66-70.

14. Машковский МД. Лекарственные средства. Москва: Новая волна; 2012.

15. Рослый ИМ, Абрамов СВ, Водолажская МГ, Шуляк ЮА. Биохимические показатели плазмы крови в оценке метаболических особенностей патогенеза алкоголизма. Вестник Ставропольского государственного университета. 2005;42:119-128.

16. Студенцов ЕП, Рамш СМ, Казурова НГ, Непорожнева ОВ. Адаптогены и родственные группы лекарственных препаратов: 50 лет поисков. Обзоры по клинической фармакологии и лекарственной терапии. 2013;11(3):3-43.

17. Шабанов ПД. Адаптогены и антигипоксанты. Обзоры по клинической фармакологии и лекарственной терапии. 2003; 2(3):50-80.

18. Danesi F, Saha S, Kroon PA, Glibetić M, Konić-Ristić A, D’Antuono LF, et al. Bioactive-rich Siderites scardiac tea (mountain tea) is as potent as Camellia sinensis tea at inducing cellular antioxidant defences and preventing oxidative stress. Journal of the Science of Food and Agriculture. 2013;93(14):3558-3564. DOI: 10.1002/jsfa.6214.

19. Gonzales-Burgos E, Carretero ME, Gomes-Serranillos MP. Sideritis spp.: uses, chemical composition and pharmacological activities. Journal of Ethnopharmacology. 2011;135(2):209-225. DOI: 10.1016/j.jep.2011.03.014.

20. Siderites scandiac. In: Lim TK. Edible medicinal and nor medicinal plants. Volume 8. Flowers. [Netherlands]: Springer; 2014. p. 207-214. DOI: 10.1007/978-94-017-8748-2.

21. Ifie I, Marshal LJ, Ho P. Hibiscus sabdariffa (Roselle) extract and wine: phytochemical profile, physicochemical properties and carbohydrase inhibitors. Journal of Agricultural and Food Chemistry. 2016;64(24):4921-4931. DOI: 10.1021/acs.jafc.6b01246.

22. Рогачев АД. Фитохимическое исследование Rhododendron adamsii Rehder. Новосибирск: Новосибирский государственный университет; 2009.

23. Мирович ВМ, Федосеева ГМ, Левента АИ. Определение суммарного содержания флавоноидов в наземной части Rhododendron adamsii спектрофотометрическим методом. Растительные ресурсы. 2005;4:67-73.

24. Rogachev AD, Komarova NI, Korchagina DV, Dolgikh MP, Sorokina IV, Baev DS, et al. Some prenylated phenols of Rhododendron adamsii: isolation, modification and pharmacological tests. Chemistry for Sustainable Development. 2008;1:17-22.

25. Губич ОИ, Пучкова КВ, Залесская НА, Крючкова НВ. Исследование адаптогенных свойств рододендрона Адамса (Rhododendron adamsii Rehder) на экспериментальных моделях in vivo. Журнал Белорусского государственного университета. Биология. 2018;1:60-68.

26. Губич ОИ, Капанева АП, Бурак ЕВ. Сравнительная эффективность регуляции природными адаптогенами углеводного обмена крыс с экспериментальным сахарным диабетом. Журнал Белорусского государственного университета. Биология. 2018;3:14-20.

27. Камышников ВС. Справочник по клинико-биохимической диагностике. Минск: Медпресс-информ; 2009.

28. Aebi H. Catalase in vitro. Methods in Enzymology. 1984;105:121-126. DOI: 10.1016/S0076-6879(84)05016-3.

29. Костюк ВА, Потапович АИ, Ковалева ЖВ. Простой и чувствительный метод определения активности супероксиддисмутазы, основанный на реакции окисления кверцетина. Вопросы медицинской химии. 1990;36(2):88-91.

30. Северин СЕ, Соловьева ГА. Практикум по биохимии. Москва: МГУ; 1989.

31. Губич ОИ. Медицинская биохимия. Минск: БГУ; 2015.

32. Тарасова ОИ, Огурцов ПП, Мазурчик НВ, Моисеев ВС. Современные лабораторные маркеры употребления алкоголя. Клиническая фармакология и терапия. 2007;16(1):1-5.

33. Ковалев ГА, Петренко АЮ. Экспериментальная модель алкогольного поражения печени у самок крыс. Вестник Харьковского национального университета. 2004;617(8):15-18.

34. Ливзан МА, Лялюкова ЕА. Алкогольная болезнь печени: современные аспекты диагностики и лечения. Медищинский совет. 2014;13:49-53. DOI: 10.21518/2079-701X-2014-13-49-53.

35. Яременко КВ. Учение Н. В. Лазарева о СНПС и адаптогенах как базовая теория профилактической медицины. Психофармакология и биологическая наркология. 2005;5(4):1089-1092. 


\section{References}

1. Afanasyev AV, Afanasyev VV, Rubitel LT. Ostraya intoksikatsiya etilovym alkogolem [Acute toxicity by ethyl alcohol]. Saint Petersburg: Intermedika; 2002. Russian.

2. Ilnitski AN, Zhernakova NI, Postnikova LI, Borisov OA, Pozdnyakova NM. Molecular mechanisms of neuroimmunoendocrine effects of alcohol. Belgorod State University Scientific bulletin: Medicine. Pharmacy. 2011;13(4(99)):5-12. Russian.

3. Razvodovsky YE. [Alcoholic cardiomyopathy: current state of the problem]. Zdravookhranenie. 2007;4:42-45. Russian.

4. Crews F, Nixon K, Kim D, Joseph J, Shukitt-Hale B, Qin L, et al. BHT blocks NF-kappaB activation and ethanol-induced brain damage. Alcoholism Clinical and Experimental Research. 2006;30(11):1938-1949. DOI: 10.1111/j.1530-0277.2006.00239.x.

5. Schegolev AI, Tumanova UN. The role of alcohol in the occurrence of liver cancer. International Journal of Applied and Fundamental Research. 2017;11(2):223-227. Russian.

6. Walsh K, Alexander G. Alcoholic liver disease. Postgraduate Medical Journal. 2000;76(895):280-286. DOI: 10.1136/pmj. 76.895 .280

7. Seitz HK, Stickel F. Molecular mechanisms of alcohol-mediated carcinogenesis. Nature Reviews Cancer. 2007;7(8):599-612. DOI: $10.1038 / \mathrm{nrc} 2191$.

8. Klyaritskaya IL, Iskova IA. The role of alcohol in the development of gastrointestinal cancer. Krymskii terapevticheskii zhurnal. 2017;2(2):18-23. Russian.

9. Tumanova UN, Shchegolev AI. Angiogenesis in hepatocellular carcinoma. Uspekhi sovremennoi biologii. 2015;135(2): 164-176. Russian.

10. Eremina EY. [Alcoholic liver disease]. Arkhiv vnutrennei meditsiny. 2012;6(8):26-30. Russian. DOI: 10.20514/2226-67042012-0-6-50-54

11. O'Shea RS, Dasarathy S, McCullough AJ. Alcoholic liver disease. Hepatology. 2010;51(1):307-328. DOI: 10.1002/hep.23258.

12. Sholomitskaya IA, Kapralov NV. Alkogol'naya bolezn' pecheni [Alcoholic liver disease]. Minsk: Belarusian State Medical University; 2015. Russian.

13. Razvodovsky YuE. [Alcoholic liver damage]. Meditsinskie novosti. 2003;7:66-70. Russian.

14. Mashkovsky MD. Lekarstvennye sredstva [Medicines]. Moscow: Novaya volna; 2012. Russian.

15. Roslyj IM, Abramov SV, Vodolazhskaya MG, Shulyak UA. Biochemical parameters of plasma as metabolic features patogenesis of the alcoholism. Vestnik Stavropol'skogo gosudarstvennogo universiteta. 2005;42:119-128. Russian.

16. Studentsov EP, Ramsh SM, Kazurova NG, Neporozhneva OV. Adaptogens and related groups of drugs: 50 years of searching. Reviews on Clinical Pharmacology and Drug Therapy. 2013;11(3):3-43. Russian.

17. Shabanov PD. [Adaptogens and antihypoxants]. Reviews on Clinical Pharmacology and Drug Therapy. 2003;2(3):50-80. Russian.

18. Danesi F, Saha S, Kroon PA, Glibetić M, Konić-Ristić A, D'Antuono LF, et al. Bioactive-rich Siderites scardiac tea (mountain tea) is as potent as Camellia sinensis tea at inducing cellular antioxidant defences and preventing oxidative stress. Journal of the Science of Food and Agriculture. 2013;93(14):3558-3564. DOI: 10.1002/jsfa.6214.

19. Gonzales-Burgos E, Carretero ME, Gomes-Serranillos MP. Sideritis spp.: uses, chemical composition and pharmacological activities. Journal of Ethnopharmacology. 2011;135(2):209-225. DOI: 10.1016/j.jep.2011.03.014.

20. Siderites scandiac. In: Lim TK. Edible medicinal and nor medicinal plants. Volume 8. Flowers. [Netherlands]: Springer; 2014. p. 207-214. DOI: 10.1007/978-94-017-8748-2.

21. Ifie I, Marshal LJ, Ho P. Hibiscus sabdariffa (Roselle) extract and wine: phytochemical profile, physicochemical properties and carbohydrase inhibitors. Journal of Agricultural and Food Chemistry. 2016;64(24):4921-4931. DOI: 10.1021/acs.jafc.6b01246.

22. Rogachev AD. Fitokhimicheskoe issledovanie Rhododendron adamsii Rehder [Phytochemical study of Rhododendron adamsii Rehder]. Novosibirsk: Novosibirsk State University; 2009. Russian.

23. Mirovich VM, Fedoseeva GM, Leventa AI. [Determination of the total content of flavonoids in the ground part of Rhododendron adamsii by the spectrophotometric method]. Rastitel'nye resursy. 2005;4:67-73. Russian.

24. Rogachev AD, Komarova NI, Korchagina DV, Dolgikh MP, Sorokina IV, Baev DS, et al. Some prenylated phenols of Rhododendron adamsii: isolation, modification and pharmacological tests. Chemistry for Sustainable Development. 2008;1:17-22.

25. Hubich AI, Puchkova KV, Zalesskaya NA, Kryuchkova NV. The investigation of the adaptogenic properties of Rhododendron adamsii Rehder. on experimental models in vivo. Journal of the Belarusian State University. Biology. 2018;1:60-68. Russian.

26. Hubich AI, Kapaneva AP, Burak EV. The comparative efficiency of the carbohydrate exchange regulation in rats with experimental diabetes mellitus by natural adaptogens. Journal of the Belarusian State University. Biology. 2018;3:14-20. Russian.

27. Kamyshnikov VS. Spravochnik po kliniko-biokhimicheskoi diagnostike [Handbook of clinical and biochemical diagnostics]. Minsk: Medpress-inform; 2009. Russian.

28. Aebi H. Catalase in vitro. Methods in Enzymology. 1984;105:121-126. DOI: 10.1016/S0076-6879(84)05016-3.

29. Kostiuk VA, Potapovich AI, Kovaleva ZhV. A simple and sensitive method of determination of superoxide dismutase activity based on the reaction of quercetin oxidation. Voprosy meditsinskoi khimii. 1990;36(2):88-91. Russian.

30. Severin SE, Solovyova GA. Praktikum po biokhimii [Workshop on biochemistry]. Moscow: Moscow State University; 1989. Russian.

31. Hubich AI. Meditsinskaya biokhimiya [Medical biochemistry]. Minsk: Belarusian State University; 2015. Russian.

32. Tarasova OI, Ogurtsov PP, Mazurchik NV, Moiseev VS. [Modern laboratory markers of alcohol use]. Klinicheskaya farmakologiya i terapiya. 2007;16(1):1-5. Russian.

33. Kovalev GA, Petrenko AYu. An experimental model of alcohol induced hepatic injury at female rats. Vestnik Khar'kovskogo natsional'nogo universiteta. 2004;617(8):15-18. Russian.

34. Livzan MA, Lyalukova EA. [Alcoholic liver disease: modern aspects of diagnosis and treatment]. Meditsinskii sovet. 2014; 13:49-53. Russian. DOI: 10.21518/2079-701X-2014-13-49-53

35. Jaremenko KV. The N. V. Lazarev's theory of State Unspecific Increased Resistance (SUIR) and adaptogens as the basic of preventive medicine. Psikhofarmakologiya i biologicheskaya narkologiya. 2005;5(4):1089-1092. Russian. 